\title{
Paideusis
}

\section{Back to the Rough Ground: Phronesis and Techne in Modern Philosophy and in Aristotle (Joseph Dunne)}

\section{Paul O'Leary}

Volume 9, Number 2, 1996

URI: https://id.erudit.org/iderudit/1073244ar

DOI: https://doi.org/10.7202/1073244ar

See table of contents

Publisher(s)

Canadian Philosophy of Education Society

ISSN

0838-4517 (print)

1916-0348 (digital)

Explore this journal

Cite this review

O'Leary, P. (1996). Review of [Back to the Rough Ground: Phronesis and Techne in Modern Philosophy and in Aristotle (Joseph Dunne)]. Paideusis, 9(2), 33-35. https://doi.org/10.7202/1073244ar viewed online.

https://apropos.erudit.org/en/users/policy-on-use/ 


\section{Book Reviews}

\section{Joseph Dunne, Back to the Rough Ground:Phronesis and Techne in Modern Philosophy and in Aristotle. Notre Dame: Notre Dame Press, 1993.}

In this lengthy, subtle, and densely argued book, Dunne seeks to recover a conception of practical rationality which has been obscured by the contemporary inclination to view all our practical engagements solely in terms of technical reason. One example of this bias and one which originally stimulated Dunne's quest is the behavioural objectives model of teaching. On this approach, effective teaching requires the specification of intended learning outcomes and these, in turn, guide the selection and evaluation of methods, classroom activities, and learning materials. This model of rationality for teaching exemplifies an instrumentalist conception of reason since it "sought to separate ends and means, to repose everything of value that a teacher might accomplish in the ends (i.e., objectives) and, then, to construe all problems of teaching as ones simply of finding the most suitable means to the achievement of these ends" (p. 5). Not only does Dunne think that the instrumentalist conception of rationality distorts our view of the educational engagement, but it is also at the basis of serious misunderstandings of other human practices such as religion, art, politics, and the ethical life. His enterprise, then, is to give us a perspicuous view of the sort of non-instrumental rationality which can be found at work within educational and other practices. This amounts to a recovery since a conception of noninstrumental rationality as well as its differences from instrumental reason can already be found in Aristotle's distinction between phronesis and techne.

Dunne's treatment of Aristotle takes place in Part 2 of the book while Part 1 deals with the retrieval of the phronesis-techne distinction conducted by some modern philosophers. Thus, the opening three chapters deal respectively with Newman, Collingwood, and Arendt and are intended to illustrate how each of these thinkers has consciously gone about revealing the limitations of technical reason when the latter attempts to engulf such practices as religion, art, and politics. Dunne's selection of these three thinkers, as well as his selection of Gadamer and Habermas, discussion of whom completes Part 1, does not, in Dunne's view, represent the only possible selection. Indeed, Dunne admits that Oakeshott's well-known criticisms of rationalism in politics could have served his purposes just as well as his discussion of Arendt's The Human Condition. What this particular array of philosophers does reflect are the "books that come to hand at particular times while others remained at large, of some trails followed up while others were allowed to run dead, of influences already established and scarcely recognizable, that disposed this way and not that"' (p. 27). In short, chance brought about this selection. But the one philosopher whose selection is not a matter of chance but necessary to Dunne's project is Aristotle.

What kind of knowledge does the professional teacher need to have? According to what might be called the standard view, teachers need a certain amount of theoretical knowledge which can then be applied to particular teaching situations. According to Dunne, Aristotle's conception of theory is such that it would be particularly flat-footed in providing guidance to any practice since, for Aristotle, the object-domain of theory at its highest reaches is "limited to necessary and eternal being" (p. 238). However, with the rise of the natural and social sciences, the conception of theoretical knowledge and its objects has 
undergone significant change. On one reading, such enquiries attempt to seek out the underlying law-like regularities which govern phenomena and, in the light of knowing those regularities, a technology can be established in which certain objects can be made or produced. This kind of knowledge is captured by what Aristotle called techne. For Aristotle, techne "provides the kind of knowledge possessed by an expert in one of the specialized crafts, a person who understands the principles ... underlying the production of an object or state of affairs, e.g., a house, a table, a safe journey, or a state of being healthy" (p. 244). What leads to the behavioural objectives model of teaching is the treatment of the knowledge a teacher needs as a kind of techne whereby a teacher is able to produce certain specifiable learning outcomes.

The beginning of an alternative view of teacher knowledge can be found in Aristotle's treatment of phronesis within the Nichomachean Ethics. Although Aristotle is mainly concerned with the sort of knowledge one needs in order to conduct one's life as a citizen of the polis, his treatment can, according to Dunne, be extended to teaching as well as other practices. Phronesis is taken to be a matter of knowing how to live well. Such knowledge is acquired differently from the way in which one learns to become technically proficient in making a certain product. In cases of techne, one can learn certain principles and rules which, when followed, reliably bring about a certain outcome since the product to be made can be specified in advance of the means taken to make it. However, what constitutes "living well" is not something which can be concretely specified in advance so as to determine just what principles and rules would ensure its coming about. The circumstances of human life are variable, transient, shifting, disconcerting, capricious, and ambiguous, thus requiring an intelligence which is agile, capable of improvisation, and ready to respond to opportunity. The acquisition and development of this kind of intelligence is not achieved by being taught certain principles and rules which are then practised, but rather through the experience of living with others. Whether one does eventually learn to live well depends on whether the polis in which one grows up has a certain degree of ethical integrity and whether those who advise the young are capable of exercising phronesis.

Oddly enough, even though the original impetus for Dunne's foray into the techne-phronesis distinction was a dissatisfaction with the behavioural objectives model of teaching, he confines his remarks about teaching to relatively few pages. The reason is not hard to find. Since he views his work chiefly as a matter of recovering an almost forgotten distinction, his book is largely given over to interpretation of certain critical texts of Aristotle as well as a few selected others. Nevertheless, he makes several remarks which make it clear that he regards rationality in teaching to require the same sort of agile intelligence operating within variable circumstances that is characteristic of phronesis. Teachers do not deliberate about the best means to an already specified end, since they need to consider the end to be pursued in a particular situation. So, even if they have a fairly rich conception of what education is, teachers still need to deliberate about what is a worthwhile and feasible educational goal for this pupil, given the depth of difficulty she experiences in certain areas, the effects on other pupils of a disproportionate amount of time given to helping her, the level of parental support available to her, or the probabilities in relation to the kind of job (if any) she is likely to have later on (p. 352). 
The kind of practical knowledge which a teacher needs to acquire in order to teach well is, like knowing how to live well, the fruit of a person's experience and character. Like learning to live well, learning to teach well presupposes the integrity of teaching as a professional practice while also requiring advice in the course of a student-teacher's classroom experience from those who are already good teachers by virtue of being firmly disposed to exercise phronesis.

Given Dunne's emphasis on the significance to student-teachers of having the right kind of classroom experience with the right kind of mentors, one wonders about what sort of role educational studies can have in the education of teachers. Here, there is an important parallel with Aristotle's views about the role of the Nichomachean Ethics in the moral education of his audience. Although human beings do not become good simply by being given lectures in philosophy since they need the right sort of experience while growing up, nevertheless such lectures do contribute to the formation of a virtuous disposition by articulating, systematising, and defending the integrity of life within the Greek polis. In similar fashion, Dunne views educational studies as contributing to the development of those dispositions which are characteristic of good teachers by articulating, systematising, and defending the integrity of teaching as a practice. Back to the Rough Ground, although largely an interpretive work, makes its contribution to teacher education by articulating the significance of the techne-phronesis distinction to our understanding of teaching, while also defending the integrity of teaching by serving as a prophylactic against the virus known as the behavioural objectives model of teaching.

\section{Reviewed by Paul O'Leary, The University of Western Ontario}

\section{John Martin Rich and Joseph L. De Vitis, Competition in Education Springfield, Ill.: Charles C. Thomas, 1992. pp. 206 + viii}

The authors hold that "the roots of competition lie deep in American culture" and competition is "reflected and reinforced by educational institutions." From this viewpoint, they note educators' periodic recognition of the importance of competition in American education, and observe that competition's "full ramifications, significance, and danger have not been fully explored." This is an interesting observation for those for whom competition for survival has now become the day's imperative. What, then, are the ramifications, significance, and dangers? To put the conclusion first, the two hundred or so pages of the book do not supply a clear answer to these questions because the discussion is loose and not well organized. Though these questions are interesting, other matters are attended to such as "various major aspects of competition in education." Included are issues like "competition within educational policies, programs, and practices, as well as the problems certain forms of competition create," and "the influences on education of competitive values in American social and economic life." The ramifications of competition are largely omitted while various policies related to competition receive cursory and insufficiently elaborated comment.

The point of departure of their discussion is the claim that the roots of competition lie deep in American culture discussed in the section, "Competitive Ethic in American Culture." All that the reader sees is a quotation from Stanley 